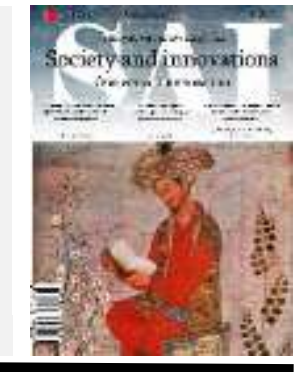

\title{
The old Ahsikent
}

\section{Bakhtiyor RUZINOV ${ }^{1}$ Abdurauf ABDULLAEV ${ }^{2}$}

Namangan State University

\begin{tabular}{l} 
ARTICLE INFO \\
\hline Article history: \\
Received January 2021 \\
Received in revised form \\
15 January 2021 \\
Accepted 20 February 2021 \\
Available online \\
7 March 2021 \\
\hline Keywords: \\
art, Somonids, Karakhanids, \\
timurid period, culture, \\
renaissance, the turkish \\
language, literature, tourism, \\
east, open-air museum, poetry.
\end{tabular}

\section{Кўхна Ахсикент}

\begin{abstract}
This article analyzes the history, culture and art of Ahsikent, the ancient capital of the Fergana Valley, the works of scholars who contributed to the development of our national spirituality and the scientists who studied it in detail.
\end{abstract}

2181-1415/C) 2021 in Science LLC.

This is an open access article under the Attribution 4.0 International (CC BY 4.0) license (https://creativecommons.org/licenses/by/4.0/deed.ru)

\section{АННОТАЦИЯ}

Мазкур мақолада фарғона водийсининг қадимий пойтахт шахри Ахсикентнинг тарихи, маданияти ва санъатининг ривожи, унинг миллий маънавиятимиз тараққиётига хисса қўшган алломалар ва уни атрофлича ўрганган олимларнинг ишлари тўғрисида тахлил қилинган.

\section{Старый Ахсикент}

\section{Ключевые слова: \\ искусство, Сомониды, Караханиды, тимуридский период, культура, \\ возрождение, турецкий \\ язык, литература, туризм,}

\section{АННОТАЦИЯ}

В статье анализируются история, культура и искусство Ахсикента, древней столицы Ферганской долины, труды ученых, внесших вклад в развитие нашей национальной духовности, и ученых, которые ее подробно изучили.

\footnotetext{
${ }^{1}$ Lecturer of the Department of Applied Arts and Painting, Namangan State University, Namangan, Uzbekistan

${ }^{2}$ Lecturer of the Department of Cultural Studies, Namangan State University, Namangan, Uzbekistan Email: abruz@mail.ru
} 
восток, музей под открытым

небом, поэзия.

Қадимда Осиёни Европа билан боғлаб турган Буюк ипак йўлининг гуллабяшнашида пойтахт шахарларнинг ахамияти катта бўлган. Бу борада қадимги Фарғона ўлкасининг пойтахтларидан бири - Ахсикент ўзига хос ўрин тутган. Камида икки минг йиллик тарихга эга қадимий шахар харобалари Тўрақўрғон ва Жомашуй орқали ўтадиган Наманган - Фарғона автойўлининг икки томонида, Сирдарёнинг ўнг сохили бўйлаб чўзилиб кетган баланд тепаликлар кўринишида ётибди.

Мазкур Эски Ахси манзилгохи Фарғона водийсидаги энг йирик археологик ёдгорлик хисобланиб, сақланиб қолган умумий ер майдони 150 гектардан зиёдни ташкил этади. Ўзига хос услубда қурилган буржлар мудофаа деворининг ташқи томонига чиқмай, унинг уцрнига деворнинг тепа сатхидан яна камида 5-6 метр баланд бўлган. Шунинг хисобига мудофаа деворининг баландлиги хам 20 метрга етган. Хозирги кунда хам ушбу буржларнинг қолдиғи мудофаа деворининг сақланган қисми сатхидан 3-4 метр баланддир. Бу даврга оид бундай махобатли мудофаа девори қолдиқлари водийнинг бошқа жойида топилмаган бўлиб, у Марказий Осиё шахар қурилиши маданиятида мухим ахамият касб этади.

Манзилгохни қазиб ўрганган қадимшунос олимлар моддий - ашёвий далиллар ва энг кўхна ёзма хитой манбаларига таянган холда шахарнинг пайдо бўлишини тахминан милоддан аввалги III асрларга тўғри келиши маълумотини берганлар. Ахсикент Буюк Ипак йўли чоррахасида жойлашган шахарлардан бири бўлиб, тарихнинг кўп даврларида Фарғона водийсининг пойтахти вазифасини ўтаган. Фарғона хақидаги дастлабки аниқ маълумотлар милоддан аввалги 128-127 йилларда бу ерларда бўлган Хитой дипломати Чжан Цяннинг 126 йилда Хитой императори УДига йўллаган хисоботида учрайди. Чжан Цянь ва ундан кейинги элчиларнинг қолдирган хабарномалари асосида Сима Цяннинг "Ши Цзи" ва Бан Гунинг "Хоу Хань шу" каби тарихий асарлари ёзилган. Ушбу йилномалар Фарғонанинг ижтимоийиқтисодий ва сиёсий хаётида Ахсикентнинг тутган ўрни хақидаги дастлабки берилган ёзма манба маълумотлари билан ахамиятлидир. “Ши Цзи”нинг муаллифи Сима Цянь Фарғонада 70 та шахар борлигини ёзган эди.

Хитой манбаларида катта қишлоқлар хам шахар, деб тилга олинган. Милодий эранинг бошларига келиб, Фарғона водийсининг дарё ва сой хавзаларидан энг унумдор ерлар тўлиқ ўзлаштирилиб, дехқончилик кенг ривожланиши баробарида халқаро савдо алоқаларининг кенгайиши, кўп тармоқли хунармандчиликнинг жадал тараққийси, кончиликнинг тезкорлик билан ўсиши шахар маданиятининг хар томонлама барқ уриб, гуллаб-яшнашига олиб келди. Бу даврда Довон давлати Сўғд, Бақтрия, Эрон, Хиндистон давлатлари ва қўшни кўчманчи қабилалар билан савдосотиқ алоқаларини юритган.

Ахсикент сингари пойтахт шахарлар эса хар томонлама ривожланган. Айниқса милоднинг V - VII асрларида шахарда беш-олти хоналик уй-жой қурилишига катта ахамият берилган.

Бу даврга келиб қитъалараро йўл Фарғона халқлари хаётида жуда мухим ўрин эгаллай бошлаган. Хусусан, VI-VII асрларда сўғд-турк савдогарлари Шарқда Хитой орқали Корея ва Япониягача, Ғарбда Ўрта Ер денгизи бўйи давлатларигача, Жанубда Хиндистон ва Цейлонгача бориб, савдо-сотиқ ишлари билан шуғулланганлар.

Ўрта асрларда Ахсикент, Афросиёб, Шохрухия, Пойканд, Термиз каби шахарларда шиша буюмлар ишлаб чиқарилганлиги маълум. Хунармандчилик ва 
амалий санъатнинг барча сохалари ривожланиши учун талаб этиладиган зарурий хом ашёлар, яъни, соз тупроқ, ранглар тайёрлаш учун хамма турдаги ўсимликлар, пахта, пилла, тери, кварц қуми, даламит, пигматит, дала шпати, каолин, қалай, жез, кумуш, олтин, темир, молибден ва бошқа рудалар Ахсикент ва унинг атрофида мавжуд эди.

Фарғона водийсида ишлаб чиқарилган махсулотлар савдоси нафақат Мовароуннахрда, балки Буюк Ипак йўли орқали бутун дунёга машхур бўлган. Ривожланган ўрта асрларда (X-XII) гуллаб-яшнаган Фарғона - Ахсикат арк, икки қисмдан иборат шахристон ва рабоддан иборат бўлиб, шахристон ва ғарбий рабоднинг асосий қисми IX асрнинг иккинчи ярми XVI асрнинг бошларида хунармандлар билан банд бўлган. Хунармандларнинг кўпчилиги темир, пўлат ишлаб чиқариш ва улардан хилма-хил буюм ва қуроллар тайёрлаш билан шуғулланган. Археологик тадқиқотлар Фарғона - Ахсикат шахрининг иқтисодий салохияти ва унинг Марказий Осиёда тутган ўрнини аниқлаш имконини берди. VIII аср охири IX аср бошларида Ахсикент шахри араб йилномаларида (Сўғд хужжатларида “Фраганик”, деб номлангани сингари) “Фарғона”, деб аталган. Яъни, пойтахт шахар, водий ва давлат бир хил номга эга бўлган. Илк араб йилномаларидан хисобланган қомусий олим Абу Жаъфар ат-Табарий (839 - 923) нинг “Тарихи ар-расул ва-л-мулук”, яъни, "Пайғамбарлар ва подшохлар тарихи" асарида Фарғона водийсидаги 5 та шахар: Хўжанд, Косон, Боб, Кубо ва Фарғона тилга олинган. Ибн Хурдодбехнинг милодий 846 йилда ёзиб тамомлаган “Китоб ал-масолик ул-мамолик” (“Йўллар ва мамлакатлар хақида китоб”) асарида Араб халифалиги қўл остидаги мамлакатлар, шахарлар хамда ўлкалар оралиғидаги масофа, ва уларга бориладиган йўллар ахолидан ундириладиган солиқ ва жарималар миқдори) хақида қисқа лекин, қимматли маълумотлар мавжуд.

Айниқса, сомонийлардан Нух ибн Асад (842 йилда вафот этган) ва Ахмад ибн Асад (819 - 864) даврларида Сўғд хамда Фарғонанинг умумий ахволи, Мовароуннахр ва Фарғонада IX асрда истиқомат қилган туркий халқлар хақидаги маълумотлар бенихоя қимматлидир. Ибн Хурдодбех VIII аср охири - IX аср бошларида Боб ва Қубо шахарлари орасида Фарғона шахри жойлашганлиги хусусида ёзиб, унинг аниқ ўрни координатларини хам кўрсатиб ўтган эди. Ёзилишича, Боб (Поп) ва Фарғона (Ахсикент) шахарларининг урртасидаги масофа 4 фарсах (1 фарсах - 8 километр), ундан Қубо (Қува) шахригача эса 10 фарсахга тенг бўлган. Демак, Бобдан Фарғона шахригача 32 км., Фарғонадан Қубогача бўлган масофа 80 км.ни ташкил этган. Хозирги Поп ва Эски Ахси ёдгорликлари орасидаги масофа 32- 35 километрга, Эски Ахсидан то Қува харобаларигача эса 80 - 85 километрга тенг. Бундан хам кўриниб турибдики, сираям иккиланмасдан, ибн Хурдодбех асарида кўрсатилган “Фарғона” шахри хозирги Эски Ахси ёдгорлиги ўрнида бўлган, деган хулосани чиқариш мумкин.

Қадимги Фарғонанинг пойтахт шахарларидан бири Ахсикат (Ахсикент) бўлган. Абдулкарим Самъоний бу шахарни Фарғонанинг энг гўзал ва озода шахарларидан эканлигини, Ёқут ал-Хамавий эса унинг Сирдарёдан бир фарсах масофада тоғлар орасидаги текисликда жойлашганлигини айтади. Унинг таъкидлашича, шахар қўрғони ва работи девор билан ўралган ва тўртта дарвозаси бор эди. Шахар атрофида боғлар, работ ичида эса кўплаб ховузлар бўлиб, анхорлар ўтган. Катта жоме масжиди, бозор, қалъа ва бошқа бинолар Ахсикентнинг ички шахар қисмида жойлашган. Атрофдаги тоғлардан олтин ва кумуш қазиб олинган.

IX асрнинг иккинчи ярмидан бошлаб Фарғона шахри араб манбаларида Ахсикат, деб юритила бошланди. Лекин, нумизматик материалларнинг гувохлик беришича, XI 
асрнинг ўрталаригача Фарғонанинг бош пойтахти икки ном билан Фарғона ва Ахсикат деб, аталган. Чунки, араб тилидаги манбаларда хам Фарғона номи бир пайтнинг ўзида давлат ва шу давлат пойтахтининг номи сифатида берилган. Ўрта асрларда Фарғона водийсида қатор катта шахарлар барпо этилганлиги ва уларда илм-фаннинг турли сохалари муваффақиятли ривожланганлиги аниқланган. Чунончи, Муқаддасий (X аср) Фарғона водийсида қирқдан зиёд катта-кичик шахарлар бўлганлигини хабарини берган. Абдулкарим Самъоний эса, тўққизта шахар, еттита қишлоқ ва битта махаллани зикр этган. Ахсикат, Косон, Марғилон, Қува, Ўш, Ўзганд, Хайлам, Қўқон, Хўжанд каби шахарлар, Андукон, Газак, Заркан, Йадухкат, Навқад, Ломиш каби қатор қишлоқлар шулар жумласидандир.

Фасих Хавофийнинг “Мажмаи Фасихий” асарида Мирзо Улуғбекнинг 1414 йил Фарғона сари қўшин тортиб, Ахсини қамал қилиб эгаллаганлиги баён этилган. Бу воқеа Абдураззоқ Самарқандийнинг "Матлаи садъайн ва мажмаи бахрайн” асарида қуйидагича тасвирланади: “...Мирзо Улуғбек кўрагон Андижонга қараб юрди. Мирзо Амирак Ахмад у ернинг қалъаларини мустахкамлаб, тоққа чиқиб кетди. Мирзо Улуғбек у ернинг энг катта қалъаси бўлган Ахси қалъасини мухосара қилди. У шундай қалъаки, унинг мезаналаридан фалак бошоқ (юлдуз)ларини териб олиш ва баланд хоналаридан фаришталар ғулғуласини эшитиш мумкин эди”. Бундан Ахсикент қўрғонининг XIV acp охири - XV аср бошларида хам Фарғона водийсидаги мустахкам мудофаа деворларига эга, стратегик ахамиятга молик шахар-қўрғон бўлганлиги аён бўлади. XV acрнинг иккинчи ярмига келиб темурийлар даврида Ахсикент шахри яна қайтадан пойтахтга айлантирилди. Темурийзода Умаршайх Мирзо бу шахарни пойтахт қилиб танлаб, 1494 йилгача мамлакатни шу ердан туриб бошқарди.

Профессор Н.Н.Веселовский Эски Ахсини ўрганиш юзасидан берган хисоботида шахар XV асрда хам мавжудлигини, тадқиқотчи И.А.Кастанье эса темурийлардан Умаршайх Мирзо, шайбонийлардан Жонибек Султон айнан Эски Ахсидан туриб мамлакатни бошқарганликларини ёзган эди. Ахси шахри 1621 йилда рўй берган дахшатли зилзила оқибатида халокатга учраган. Кейинчалик Ахсида юз берган зилзила тўғрисида XVII аср тарихчиси Тохир Мухаммад бинни Имомуддин Сабзоворий “Тарихи табоқот ут-Тохирий” китобида маълумотлар келтирган. Мазкур маълумотлар Исхоқхон Жунайдуллохўжа Ибратнинг “Тарихи Фарғона” асарида хам ўз ифодасини топган: “...ўша пайтдаги Фарғона пойтахти Ахси шундай вайрон бўлганки, неча минглаб одамлар иморатлар остида қолганлар. Биринчи куни етмиш марта қимирлаган, олти ойгача силкиниш давом этган...”.

Косонсойлик машхур географ ва табиатшунос олим Саййид Мухаммад Тохир ибн Абдул Қосим томонидан 1640 йилда ёзилган “Ажойиб ут-табоқот" ("Минтақалар ажойиботлари”) асарида ёзилишича, муаллиф зилзила оқибатларини ўз кўзи билан кўрган. Воқеа шундай тасвирланган: “...Хижрий йили билан 1030 йилда (милодий 1621 йил) Ахси вилоятида шундай зилзила бўлдики, Сирдарёдан чайқалиб чиққан сув дарё четидаги далани босиб кетди, сув билан чиқариб ташланган балиқлар типирчилади ва ўлди. Катта дарахтлар илдизи билан юлиниб, ерга тушди. Иморатлар қаттиқ ва тез-тез зилзиладан вайрон бўлиб, кўп одам йиқилган иморатлар остида қолиб ўлди. Кўп одамнинг оёқ-қўли синди, хайвонлар қўрқинчдан далаларга қараб қочди. Олти ойгача зилзила шундай бўлиб турди. Масалан: биринчи куни зилзила 70 мартагача бориб етди. Шуниси қизиқки, энг қаттиқ зилзила Ахси қўрғонининг ичида бўлиб, атроф қишлоқларда унча қаттиқ 
бўлмади. Шахардан бир фарсах (6-8км) ерда хеч қандай товуш эшитилмади." Ана шу вайронгарчиликдан кейин Ахси қалъа шахри қайта тикланмади.

Ахсикент юртимиздан етишиб чиққан кўплаб алломаларнинг киндик қони тўкилган муборак замин хамдир. Хусусан, Абул Қосим Махмуд ибн Мухаммад ас-Сўфий Ахсикатий (“Устози аввал”), “Зул Фазоил” (“Фазилатлар сохиби”) номи билан шухрат қозонган Абу Рашод Ахсикатий, “Зул Маноқиб” (“Мақтовга сазовор хислатлар эгаси”) лақабини олган Абул Вафо Мухаммад ибн ал-Қосим ал-Ахсикатий, “Малики шуаро” (“Шоирлар подшоси”) ва “Амири шуаро” (“Шоирлар амири”) даражасига эришган Абдул Фазл Мухаммад Тохир Асириддин Ахсикатий, Тожуддин Абу Бакр бин Ахмад алАхсикатий ал-Хўжандий (“Бош фатвочи”), Сайфиддин Ахсикатий, Мавлоно Поянда Охун Ахсикатий (“Муршиди комил”), Ал-Хусайн ибн Абу Баъли Абу Али ал-Ахсикатий ал-Фарғоний, Дамашқда “Фахрул ислом” унвонини олган Абу Саъид Мусъида ибн Бакр ал-Фарғоний, - Хисомуддин Ахсикантий - "Имом Ахсикатий" ва "Муқаййад мужтахид” унвонига сазовор бўлган, Мухаммад Юсуф ибн Имомуддин Ахсикатий, Иброхим ибн Юсуф бин Имомуддин Ахсикатийлар диний ва дунёвий илмлар сохасида шухрат қозонганлар. Яна шуни айтиш жоизки, кейинги тадқиқотлар натижасида янгиянги ахсикантий тахаллусли олимларнинг номлари манбаларда учрамоқда.

Шахарнинг Ислом дини кириб келганидан кейинги, яъни, ўрта асрлар даври тарихини ёритишда эса асосан араб, форс хамда туркий тилли манбалардан фойдаланамиз. Ўрта аср тарихчи ва географлари - Балазурий, Табарий, алМуқаддасий, Ёқут ал-Хамавий, ибн Хавқал, ибн Хўрдодбех, Абу Зайд Ахмад ибн Сахл ал-Балхий, Истахрий, Саййид Мухаммад Тохир ибн Абдулқосим Косоний, Мухаммад бинни Нажиб ал-Бақрон, Абдураззоқ Самарқандий, Мухаммад Солих, Хофиз Таниш Бухорий, Абул Фазл Алломий, Мирхонд, Абул Фазл Байхақий, ал-Фосих Хавофий, Хондамир, Захириддин Мухаммад Бобур, Мирзо Мухаммад Хайдар, Махмуд ибн Вали, Саййид Мухаммад Тохир ибн Абдул Қосим асарларида Ахсикентнинг географик жойлашув ўрни, ўлка ижтимоий-сиёсий хаётидаги ахамияти хақидаги маълумотлар келтирилган.

Ахси, Ахсикат номлари билан аталувчи шахар - Ахсикентни XIX аср охири XX аср бошларида рус шарқшунос ва археолог олимларидан, академиклар А.Миддендорф ва В.Бартольд, профессорлардан Н.Н.Веселовский хамда А.Н. Бернштам, тадқиқотчишарқшунослар И.А.Кастанье, В.Наливкин, Н.П.Остроумов, Н.Павлов ва бошқалар хам археологик ва манбавий асослар асосида ўрганганлар. Шундан кейин 1939 йилда Катта Фарғона канали қурилиши даврида профессор М. Е. Массон бу ерда археологик разведка ишлари билан шуғулланиб, 2 минг йил муқаддам бу ерда улкан шахар бўлганлиги хақидаги хулосани берди. 1948 йилда эса А.Н.Бернштам Ахсикент ёдгорлигининг лойихасини чизди, айрим жойларда қазилма ишларини ўтказган. 1960 йил 14 майдан 20 июнигача Ўзбекистон Фанлар Академиясининг академиги Яхё Ғуломов бошчилигидаги махсус отряд мутахассислари И. Ахроров, С. Рахимов, Й. Қосимов, А. Анорбоев, Папа Христо, Ғулом Мирзалиев, Қахрамон Асқаров, Фарход Мақсудов, Алижон Вохидов ва бошқа тадқиқотчи олимлар томонидан эса 1967-1969, 1971-1977, 1980-1990 ва ундан кейинги йилларда хам бу ерда илмий изланишлар ўтказилиб, мухим маълумотлар, ашёвий далиллар тўпланмоқда. И.Ахроров ўзининг 1960 йилги экспедиция фаолиятининг натижалари тўғрисидаги хулосаларини “Ўзбекистонда ижтимоий фанлар” журналидаги мақоласида Эски Ахси ёдгорлиги XVII асрдаги зилзила оқибатида вайронага айланганини баён этди. Шунингдек, муаллиф 
Захириддин Мухаммад Бобур “Бобурнома” асарида кўрсатиб ўтган Ахси қалъаси айнан бугунги кундаги Эски Ахси археологик ёдгорлиги эканлигини хам ёзган эди.

Тили ва диний эътиқоди хар хил бўлишига қарамай, Ўрта Осиё, жумладан, Фарғона халқлари ёнма-ён, тинч-тотув хаёт кечирганлар. Бу ўз навбатида иқтисодий юксалишга олиб келган. Лекин шунга қарамай шахар 1621 йилги зилзила натижасида бутунлай вайронага айланган. Шундан кейин бу ерда шахар қайта тикланмади. Ахсикент Буюк Ипак йўли тизимидаги асосий катта шахарлардан бири бўлганлиги боис, уни археологик жихатдан ўрганиш нафақат Ўзбекистон балки, умумжахон тарихи учун хам ахамиятлидир. Юқоридагиларни инобатга олган холда, 2017 йилнинг 16 октябрида Ўзбекистон Республикаси Вазирлар Махкамасининг "Наманган вилоятининг Тўрақўрғон туманида «Ахсикент» археология мероси объектини мухофаза қилиш ва тадқиқ этиш ёдгорлик мажмуасини ташкил этиш тўғрисида" ги 831-сонли Қарори қабул қилинди. Ушбу қарор орқали Фарғона водийсининг қадимий пойтахти Ахсикент тарихининг қайтадан ўрганилиши учун асос бўлди.

Ўзбекистон Республикаси Президенти Шавкат Мирзиёевнинг 2019 йил 28 февраль 1 март кунлари Наманган вилоятига хусусан, Ахсикент мажмуасига ташрифи ёдгорликни "Очиқ осмон остидаги музей"га айлантириш борасида ишларни самарали ташкил этишда мухим ахамиятга эга бўлди. Давлатимиз рахбари Ахсикент темурийзода Умаршайх Мирзо давлатининг пойтахти бўлганлигини, шахар тарихини бирламчи, ишончли манбалар асосида қайтадан ёзиб халққа етказиш лозимлигини уқтириб ўтдилар.

Шунингдек, Президент Шавкат Мирзиёев Ўзбекистонда археология фанини ривожлантириш борасида бир қатор таклифларни билдириб ўтди. Ахсикентда республика олий таълим муассасаларининг тарих ва археология йўналиши талабаларининг дала амалиётини ўтказиш, хар икки йилда бир маротаба “Ўтмишга саёхат”, деб номланувчи халқаро тарихий, археологик-этнографик фестивал ўтказиш, халқ таълими муассасалари ўқувчиларида ўтмишга бўлган қизиқишни уйғотиш мақсадида Ахсикент ёдгорлигига синфдан ташқари мунтазам экскурсиялар уюштириш ва шу асосда “Ёш қадимшунослар” мактабини ташкил этиш, сафар таассуротлари асосида иншолар танловини ўтказиш мақсадида "Буюк тарихдан-буюк келажак сари" шиори остида босқичма-босқич амалга ошириладиган тадбирлар жадвалини ишлаб чиқиш, “Бархаёт аждодларимиз” рукни остида буюк аждодларимиз хаёти хақидаги брошюраларни нашр этиш ва вилоятдаги барча мактабларга етказиш кабилар шулар жумласидандир.

Қарорда ушбу маскандан етишиб чиккан олимлар, уларнинг ишлари хаққоний тарихий хақиқат, археологик қазиш ишлари ва туризм инфратузилмасини ривожлантириш кўрсатиб ўтилган. Бунинг учун бадиий миллий хунармандчилик махсулотларини ишлаб чиқариш мақсадида Наманган давлат университети санъатшунослик факультети таркибида кулолчилик бўлими очилди. Ахсикентда туризм инфратузилмасини ривожлантириш орқали бир неча юз киши доимий иш ўрнига эга бўлишлиги, шу билан миллий хунармандларимиз махсулотларини хам реализация бўлишлигига, халқаро сахнага чиқиш имқонияти яратилади.

Хулоса ўрнида ўйлаймизки, жамланган янги маълумотлар Наманган хусусан, Фарғона водийсининг қадимий тарихини, ўтмишини, маданиятини, санъатини, меъморчилик тарихини ўрганаётган тадқиқотчилар-меъмор, тарихчи, санъатшунос ва бошқа мутахассислар учун унинг тарихий-маданий меросимизда тутган ўрнини 
аниқлашда мухим кўмак бўлиб хизмат қилади. Бундан ташқари тақдим этилаётган Ахсикент археологик объекти ушбу ўлка тарихи хақида эшитган барчани қизиқтириб, вилоятга мамлакатимиз ва дунёнинг турли томонларидан кўпдан-кўп сайёхлар келишини таъминлайди деб умид қиламиз.

\section{ФОЙДАЛАНИЛГАН АДАБИЁТЛАР РЎЙХАТИ:}

1. Ўзбекистон Республикаси Вазирлар Махкамасининг 2017 йил 16 октябрдаги «Наманган вилоятининг Тўрақўрғон туманида «Ахсикент» археология мероси объектини мухофаза қилиш ва тадқиқ этиш ёдгорлик мажмуасини ташкил этиш тўғрисида» 831- Қарори. /Постановление Кабинета Министров Республики Узбекистан от 16 октября 2017 года «0 создании мемориального комплекса по охране и изучению объекта археологического наследия «Аксикент» в Туракурганском районе Наманганской области»- Resolution of the Cabinet of Ministers of the Republic of Uzbekistan dated October 16, 2017 № 831 "On the establishment of a memorial complex for the protection and study of the object of archeological heritage Axsikent in Turakurgan district of Namangan region"/.

2. Ўзбекистон Республикаси Президентининг 2020 йилнинг 16 апрелидаги «Шарқшунослик сохасида кадрлар тайёрлаш тизимини тубдан такомиллаштириш ва илмий салохиятни ошириш чора-тадбирлари тўғрисида»ги 4680 Қарори. /Постановление Президента Республики Узбекистан от 16 апреля 2020 года № 4680 «0 мерах по кардинальному совершенствованию системы подготовки специалистов в области востоковедения и повышению научного потенциала»- Resolution of the President of the Republic of Uzbekistan dated April 16, 2020 № 4680 “On measures to radically improve the system of training in the field of Oriental Studies and increase scientific capacity"/.

3. Исмоилов Ю. Наманган фахри.-Наманган: Наманган нашриёти, 1994.

4. Исмоилов Ю., Рўзинов Б. Ахсикент-қадимги фарғона пойтахти.- Наманган: Наманган нашриёти, 2013. Исхоқхон тўра Ибрат. Тарихи Фарғона.-Тошкент: Маънавият, 2005.

5. 19. Мирзо Мухаммад Хайдар Аёзий. Тарихи Рашидий.- Тошкент: Ўзбекистон, 2011.

6. Мухаммад муфтий Охангароний. Мавлоно Лутфуллох маноқиби.- Тошкент: Имом ал-Бухорий жамғармаси, 2002.

7. Нуриддинов А. Махдуми Аъзам Косоний.-Тошкент: Фан, 2008.

8. Ртвеладзе Э.В. Узбекистан в эпоху Ахмада ал-Фергани и Имама ал-Бухари: вехи политической истории // ОНУ. №12. С. 3-10.

9. Қозоқов Т. Ахси - Фарғона шахарларининг онаси.- Тошкент: Наврўз, 2018.

10. Қозоқов Т., Рўзинов Б., Вохидов А. Ибрат нигохидаги Ахсикент.-Тошкент: Наврўз, 2018.

11. Қориев О. Ал-Марғиноний машхур фиқхшунос.- Тошкент: Мерос, 2000.

12. Рўзинов Б, Режабова С, Исмоилов Ю, Қосимов А. Наманган вилояти маданий мероси.- Наманган: Наманган, 2013.

13. Қозоқов Т, Рўзинов Б, Вохидов А. Буюкларга бешик бўлган Ахсикент ёхуд Фарғона алломалари.- Тошкент: Наврўз, 2020. 